\title{
Design and Development of a Vertical Paddle Semi Automated Garri Frying Machine
}

\author{
${ }^{1 *}$ NWADINOBI, CP; ${ }^{2}$ EDEH, JC; ${ }^{3}$ MEJEH, KI \\ ${ }^{I *}$ Department of Mechanical Engineering, Abia State University, Uturu, Abia State, Nigeria. \\ ${ }^{2}$ Department of Mechanical Engineering, Michael Okpara University of Agriculture, Umudike, Nigeria \\ ${ }^{3}$ Department of Mechanical Engineering, Abia State Polytechnic, Aba, Abia State, Nigeria. \\ *Corresponding Author Email address: chibundop@gmail.com
}

\begin{abstract}
Garri frying is the most critical unit operation in the processing of cassava into garri. The quality of the final product is much dependent on this processing stage which is a combination of simultaneous cooking and drying processes. This work presents the development of a garri fryer and the performance evaluation of the machine at various operational parameters. The fryer throughput capacity, $(\mathrm{TP})_{\mathrm{C}}$ and functional/drying efficiency, $\eta_{g}$ were used to evaluate the performance of the fryer. The cooking and drying performance of the developed machine accounted for throughput capacity of $20.66 \mathrm{~kg} / \mathrm{hr}$ and functional efficiency of $66 \%$. In addition, a preferred final moisture content of $12.14 \% \mathrm{w} . \mathrm{b}$. was achieved at $20 \mathrm{rpm}$ paddle speed and frying time of 23 minutes. The equipment have addressed the short coming observed in the village technique such as time-consumption, health hazard for the operator. In addition, it is user friendly as it requires no skilled labour and also uses different heat sources for convenience of the user.
\end{abstract}

DOI: https://dx.doi.org/10.4314/jasem.v23i7.14

Copyright: Copyright (C) 2019 Nwadinobi et al. This is an open access article distributed under the Creative Commons Attribution License (CCL), which permits unrestricted use, distribution, and reproduction in any medium, provided the original work is properly cited.

Dates: Received: 26 May 2019; Revised: 29 June 2019; Accepted 07 July 2019

Keywords: Cassava, Design, Garri fryer, operational parameters, performance evaluation

Cassava, biologically known as "manihot esculenta crantz" is a crop with many varieties. The variety common in the southern part of Nigeria grows fully at a height of between 0.6 to $2 \mathrm{~m}$. The cultivation of the cassava crop is by the propagation of stem cuttings. At maturity, the roots are dug up from the soil, and ready for processing (Olusegun and Ajiboye, 2009). Garri is a popular staple food in Nigeria and is processed from cassava tubers. Among the various food products processed from cassava tubers, garri remains the most processed, (Ohimain et al., 2013). Garri is a creamywhite coloured grainy flour made from fermentation and gelatinization processes of cassava tubers which has faintly flavor and sour taste (Rufus and Odo, 2018). On the operations used in garri production, the cassava root is peeled and washed, grated into pulp and allowed to ferment, then dewatered. The dewatered mesh is partially gelatinized, dry fried (sometimes with palm oil) to some percentage dryness of about $12 \%$ and cooled (Odigboh, 1983; Akinyemi and Akinlua, 1999; Olukunle and Ademosun, 2006; Olukunle and Oguntunde, 2008; Olukunle and Atere, 2009). Garri frying, involves a simultaneous cooking and dehydrating operation. The process goes with cooking the cassava mash with the moisture in it and then followed by dehydration to get the final garri product. The intensity heat used for the frying often determines the quality of the garri. It is expected that the moisture content of cassava mash after pressing ranges between is between 45 to $60 \%$ which is reduced to about $12 \%$ at the end of the garri frying operation. (Igbeka, 1995; Gbasouzor and Maduabum, 2012; Olagoke et al, 2014). The process of frying garri makes the product safe for human consumption. The heat supplied for this process helps in destroying the hydro cyanide acid, thus reducing its content in cassava mash to safe level and also reduces the moisture content in cassava to a safe level for storage. Garri frying process have been done using the traditional/manual technique and the mechanized method. In garri processing using the traditional/manual technique, relatively low temperature is employed at the initial frying time. This is aimed at preventing the formation of lumps or caking of the gelatinized cassava mash. This is further achieved by constant pressing and agitation of the system. As the frying time progresses, the heat is increased to further cook and dehydrate the garri. Based on choice, the processor may decide to add few drops of palm oil to improve on the product colour and taste. During garri frying, it is necessary to regulate heat input with time during frying to avoid caking; adequate agitation and pressing to break lumps formed and ensuring that the final product is cooked and dehydrated. In Nigeria, many researchers have considered ways to improve garri frying such as the UNIIBADAN improved dryer (Igbeka, 1995). Odigboh and Ahmed (1984) designed a continuous 
process garri frying machine to simulate the traditional manual frying technique. In addition, the International Institute of Tropical Agriculture, Ibadan, Nigeria (IITA) and Rural Agro-Industrial Development Scheme (RAIDS) developed an improvement on the UNIIBADAN design. Other models include the Newell Dunford model which was collaboration between the Newell Dunford company in London and the Federal Institute of Industrial Reseach (FIIRO), Oshodi, the Brazillian model; the Fabrico model done by a manufacturing company in Nigeria and the UNN model (Gbasouzor and Maduabum, 2012). Despite the improvements achieved in the machines produced, such as elimination of smoke, increased capacity and rate of frying and improved working environment. Some basic principles in the traditional frying technique such as intermittent addition of the sifted cassava mash during the frying operation thus making the operation a batch process operation. Rather most of the designs adopted continuous flow process which presented significant limitation in the quality of the garri product.

Meanwhile, the most critical aspect of the garri processing have remained the frying operation. In addition, it is worthy of note to state that the manual operation of this process is very tedious, unhygienic with low throughput compared to the investment of time, money and human energy, though have till date produced the best quality of garri. Thus, a garri frying system that will produce garri which has the same quality attributes like the garri processed manually with relatively high throughput is desired. This work is aimed at developing a system that will improve manual garri frying operation which is a batch process operation by retaining the operational principle with introduction of mechanization to enhance throughput and also obtain a good quality garri. This study will merge traditional technology and the mechanized systems, to produce a desirable, affordable, available and acceptable machine that will prevent caking of the cassava mash and ensure that the final product is cooked and dehydrated. The vertical paddle rotary garri frying machine will have the capability to produce good quality garri for human consumption in commercial quantity at a faster rate.

\section{MATERIALS AND METHODS}

This section considers the materials and method utilized in the execution of the work, design analysis of the vertical paddle rotary garri frying machine, principle of operation of the system and required system assembly.

Machine Description and Principle of Operation: The vertical paddle rotary garri frying machine (Fig.1) have components/parts which include: geared electric motor (prime mover), pulley-belt speed reduction transmission system, frying compartment, mixing paddles system, delivery chute, delivery chute cover, stirrer shaft, machine frame support, heating chamber, bearings and switch. In material selection, the minimization of cost as well as selection of the appropriate material to be used for each component considering service conditions of the components were taken into consideration.

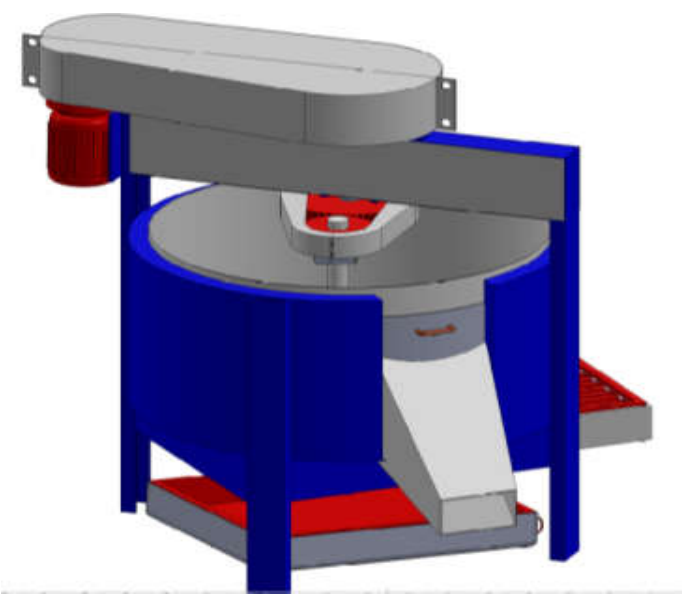

Fig 1: Complete Assembly of Garri Frying Machine

The main frame is made of C-bar mild steel of $40 \mathrm{~mm}$ by $75 \mathrm{~mm}$ and $5 \mathrm{~mm}$ thick and serve as the main supporting structure upon which other component parts of the machine are mounted. The cylindrical frying chamber is made of stainless steel metal sheet of $5 \mathrm{~mm}$ thickness, $800 \mathrm{~mm}$ diameter and depth of $304.8 \mathrm{~mm}$. The top of the frying chamber was designed to be open which serves as inlet for sieved cassava mash into the frying chamber. In addition, it provides exit for vapour during frying operation. This is aimed at preventing formation of vapour condensate within the chamber and also provides means for process inspection. The frying chamber is attached to the base where the heat source is located (cooking gas, electric heater and charcoal). The fried cassava mash (garri) discharge chute is located down side of the frying chamber. An electric motor (single phase/1.5 $\mathrm{kW} / 2 \mathrm{Hp}$ ) fitted with a reduction gear of variable speed (20 rpm to $100 \mathrm{rpm}$ ) was used to propel the frying paddle shaft and paddle to allow for the slow and gradual movement of the garri within the frying chamber. The machine also has a control box for the control of the paddles. The frying chamber has its walls attached with a coolant chamber to reduce heat loss. Heating chamber particularly generates an amount of temperature range that heats the cylinder up to $100^{\circ} \mathrm{C}$. The surroundings of the heating tray vicinity and the walls of the container are properly lagged to 
reduce heat loss. The burner has a control valve for regulating the temperature difference while using electricity.

The garri frying machine virtually operates semiautomatically; first the heating element or charged charcoal is engaged to bring the frying surface (frying chamber bottom) to the required temperature. This is achieved with the aid of the temperature regulator (for electric heater) which helps to control the heating element to a desired temperature. The sieved garri mash is fed into the frying chamber. Next the electric motor is engaged and frying commences. When the geared electric motor is engaged (switched on), it produces a rotation which is transmitted from the motor to the paddle shaft with the aid of pulleys and belt connecting the driver pulley to the driven pulley which connects the main shaft. The driver pulley is attached to the main shaft which is in connection with a driven pulley. The rotation of the driver pulley causes the driven pulley to rotate as well. When this occurs, the paddles connected to the shaft of the driven pulley rotates in a clockwise direction as well thereby, preventing the garri mash from getting burnt and from sticking together during the frying operation. The paddle rotates around the frying surface thereby pressing and agitating the garri mash thus preventing

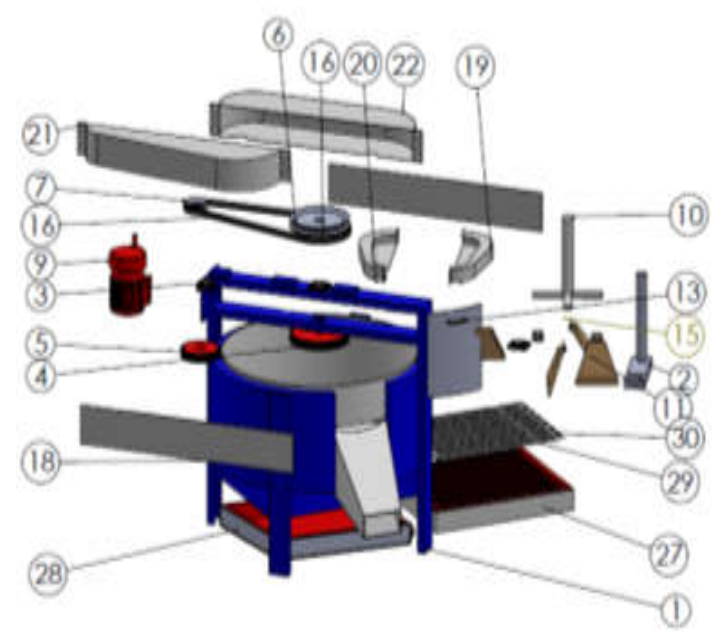

Fig 2: Exploded view of Garri Frying Machine

Design Analysis and Calculations: The Frying Chamber Design: The volume of the frying chamber can be obtain using Equation 1

$V_{c}=\pi r^{2} h$ 1

Where: $\mathrm{V}_{\mathrm{c}}=$ cylinder volume $=0.153 \mathrm{~m}^{3} ; \mathrm{r}=$ cylinder radius $=0.4 \mathrm{~m}$ and $\mathrm{h}=$ cylinder height $=0.305 \mathrm{~m}$ sticking, burning and formation of lumps during gelatinization. This continues until the garri frying is completed. After frying, the discharge chute is opened and the fried garri is discharge into a receiving container. The garri frying machine was designed to use three energy sources (cooking gag; electric heating elements and charcoal) as its source of energy.

\begin{tabular}{|c|c|c|}
\hline ITEM NO & PART NAME & QTY \\
\hline 1 & FRYING POT & 1 \\
\hline 2 & PINION CARRIER & 1 \\
\hline 3 & BEARING & 3 \\
\hline 4 & GEAR & 1 \\
\hline 5 & PINION GEAR & 1 \\
\hline 6 & 12INCH PULLEY & 1 \\
\hline 7 & PULLEY & 1 \\
\hline 8 & PULLEY SPEED REDUCER SHAFT & 1 \\
\hline $\mathbf{9}$ & MOTOR & 1 \\
\hline 10 & STEERING SHAFT & 1 \\
\hline 11 & STEERING PIN & 4 \\
\hline 12 & HING ASSEMBLY & 4 \\
\hline 13 & DISCHARGE DOOR CLOSING PLATE & 4 \\
\hline 14 & HING J17 & 4 \\
\hline 15 & HING AJ17 ASSEMB & 1 \\
\hline 16 & BELT & 1 \\
\hline 17 & BELT2 & - \\
\hline 18 & FLAT GUARD & 2 \\
\hline 19 & GEAR GUARD & 1 \\
\hline 20 & GEAR GUARD2 & 1 \\
\hline 21 & BELT GUARD1 & 1 \\
\hline 22 & BELT GUARD2 & 1 \\
\hline 27 & $\begin{array}{l}\text { ELECTRIC HEATER ELEMENT } \\
\text { CARRIER }\end{array}$ & 1 \\
\hline 28 & CHARCOAL CARRIER & 1 \\
\hline 29 & HEATING ELEMENT & 14 \\
\hline 30 & CONNECTOR & 13 \\
\hline
\end{tabular}

The maximum weight of garri the frying chamber can contain in a single batch of production can be obtained using Equation 2

$\mathrm{m}=\rho \times \mathrm{V}_{\mathrm{c}}$ 2

Where, $\rho=$ Density of garri $=1509 \mathrm{~kg} / \mathrm{m}^{3}$ (IJFST, 1989); $m=$ Mass; $V_{\mathrm{c}}=$ Volume; $m=1509 \times 0.153=$ $230.88 \mathrm{~kg}$ 
Maximum weight of garri that can be fried in the garri fryer container is calculated using Equ. 3

$W=m g$ 3

Where, $\mathrm{W}=$ Weight; $m=$ mass $=230.88 \mathrm{~kg} ; g=$ value of acceleration due to gravity $=9.8 \mathrm{~ms}^{2}$; $W=230.88 \times 9.8=2262.6 N$

Volume of cassava mash in the cylinder: Note: For effective garri frying, one-third of the volume of the cylinder will be required. Assuming the cassava mash in the cylinder is a third the volume of the cylinder, then

$\mathrm{V}_{\mathrm{m}}=\frac{1}{3} \mathrm{~V}_{\mathrm{c}}$

Where, $\mathrm{V}_{\mathrm{m}}=$ volume of mash in the cylinder; $\mathrm{V}_{\mathrm{c}}=$ volume of the cylinder

$\mathrm{V}_{\mathrm{m}}=\frac{1}{3} \times 0.153=0.051 \mathrm{~m}^{3}$

Mass of cassava mash in the cylinder:

$\mathrm{m}=\frac{\rho}{\mathrm{V}_{\mathrm{m}}}$
Where, $\rho=$ density of cassava mash $=1509 \mathrm{~kg} / \mathrm{m}^{3} ; \mathrm{V}_{\mathrm{m}}$ $=$ volume of mash in the cylinder $=0.051 \mathrm{~m}^{3} ; \mathrm{m}$ $=1509 \times 0.051=76.96 \mathrm{~kg}$

Determination of shaft and pulley speed: To calculate the shaft speed, this equation is used:

$\frac{\mathrm{D}_{1}}{\mathrm{D}_{2}}=\frac{\mathrm{N}_{2}}{\mathrm{~N}_{1}}$

Where, $D_{1}$ and $\mathrm{N}_{1}=$ Diameter $(\mathrm{m})$ and revolution of the driver pulley (rpm) respectively. $\mathrm{D}_{2}$ and $\mathrm{N}_{2}=$ Diameter (m) and revolution of the driven pulley (rpm) respectively.

To obtain the speed of the driving and driven shafts and pulleys:

$V_{1}=\frac{\pi D_{1} N_{1}}{60}$ and $V_{2}=\frac{\pi D_{2} N_{2}}{60} \quad$ (7) and (8)

Where, $V_{1}$ and $V_{2}$ are the speeds $(\mathrm{m} / \mathrm{s})$ of the driving and driven shafts and pulleys respectively.

This shaft speed is only obtained when there is no slip condition of the belt over the pulley. When slip and creep condition is present, the value is reduced by $4 \%$.

Table 1: Dimensions of standard V-belts (Khurmi and Gupta, 2005)

\begin{tabular}{lllll}
\hline $\begin{array}{l}\text { Types } \\
\text { of belt }\end{array}$ & $\begin{array}{l}\text { Power } \\
\text { ranges in kw }\end{array}$ & $\begin{array}{l}\text { Minimum pitch diameter } \\
\text { of pulley (D) } \mathbf{~ m m}\end{array}$ & $\begin{array}{l}\text { Top width } \\
(\mathbf{b}) \mathbf{~ m m}\end{array}$ & $\begin{array}{l}\text { Thickness } \\
(\mathbf{t}) \mathbf{~ m m}\end{array}$ \\
\hline A & $0.7-3.7$ & 75 & 13 & 8 \\
B & $2-15$ & 125 & 17 & 11 \\
C & $7.5-75$ & 200 & 22 & 14 \\
D & $20-150$ & 355 & 32 & 19 \\
E & $30-350$ & 500 & 38 & 23 \\
\hline
\end{tabular}

Design for belt: Selection of belt type: Based on the power transmitted (1.48 $\mathrm{kW}$ or $2 \mathrm{hp})$ and according to the Indian standards (IS: 2494-1974), belt type A was selected considering the specifications from Table 1.

Calculation of belt length, L: The equation for calculation of belt length is as shown (Khurmi and Gupta, 2005):

$L=\frac{\pi}{2}\left(D_{1}+D_{2}\right)+2 C+\frac{\left(D_{1}+D_{2}\right)^{2}}{4 C}$

Where, $\mathrm{L}=$ Length of belt $(\mathrm{mm}), \mathrm{D}_{1}=$ Smaller pulley diameter $(\mathrm{mm}), \mathrm{D}_{2}=$ Larger pulley diameter $(\mathrm{mm}), \mathrm{C}$ $=$ Centre distance of pulleys $(\mathrm{mm})$.

Heat required for the drying: The quantity of heat, $Q$ required to cook and dry the cassava mash during the garri frying process was determined using the relation in Equation 10

$\mathrm{Q}=\mathrm{MC} \Delta \mathrm{T}$

Where, $\mathrm{Q}=$ Quantity of heat required; $\mathrm{M}=$ Mass of cassava mash in the cylinder;

$C$ is the specific heat capacity of cassava mash at moisture content of $45 \% \mathrm{wb}$, given as $4.14 \mathrm{~kJ} / \mathrm{kgK}$. (Oyerinde and Olalusi, 2011); $\Delta \mathrm{T}=$ Temperature range $=\mathrm{T}_{1}-\mathrm{T}_{2}=60^{\circ} \mathrm{C} ; T_{1}$ is the initial temperature of the trough before heating $\left(40^{\circ} \mathrm{C}\right) ; T 2$ is the maximum temperature attained by the frying chamber $\left(100^{\circ} \mathrm{C}\right) ; \mathrm{Q}$ $=76.96 \times 4.14 \times 60=19126.8 \mathrm{~kJ}$

Number of belts required, ( $n)$ : The number of belts required to transmit $1.48 \mathrm{~kW}$ power from electric motor was calculated using the given equation: 
$\mathrm{n}=\frac{\text { Motor power }}{\text { power per belt }}$

Determination of Power to Drive the Shaft:

$\mathrm{P}=\frac{2 \pi \mathrm{N}_{2} \mathrm{~T}}{60}$

Where, $P=$ Power of the driven pulley; $N_{2}=$ Speed of the driven pulley; $T=$ Minimum Torque to drive maximum volume of the garri

$T=\left(W_{\mathrm{cr}}+W_{f}\right) \times R_{f}$

Where $W_{\text {cr }}=$ weight of the connecting rod; $W_{f}=$ weight of the driven pulley and $R_{f}=$ radius of driven pulley.

Performance Test Procedure: The major material used in this work is sieved cassava mash which was fried using the developed garri fryer. The cassava mash was obtained from a garri processing factory in Aba, Abia State, Nigeria. Gravimetric method was used in the determination of the moisture content of the cassava mash (AOAC, 1990). The final weight was taken when the product has cooled down inside a desiccator, the moisture content was obtained in the wet basis as:

$$
M_{c}=\frac{w_{o}-W_{f}}{w_{o}} \times 100 \% \quad(14)(\text { Olagoke et al, 2014) }
$$

Where, $\mathrm{M}_{\mathrm{c}}=$ Moisture content (wet basis), \%; $\mathrm{W}_{\mathrm{o}}=$ Weight of wet mash, $\mathrm{kg}$ and $\mathrm{W}_{\mathrm{f}}=$ Weight of dried mash, kg.

The cassava mash frying was carried out by pouring the cassava mash of known moisture content and mass intermittently into the fryer. The base of the fryer was heated up to a given temperature which was determined through the use of digital probe thermometer (thermocouple). As the moisture content reduces and most of the small lumps developed, are broken down by constant pressing and agitation, the heat is then increased to further cook and dehydrate the garri. The extent of drying depends on the rate of heat utilized and frying time.

Thereafter, test parameters that used in testing the performance of the machine are evaluated, and they are: the fryer throughput capacity, (TP) $\mathrm{C}$ and functional/drying efficiency, $\eta_{g}$. Throughput capacity which is the ratio of the quantity of garri collected after frying to the frying time.

$$
(\mathrm{TP})_{\mathrm{C}}=\frac{\mathrm{m}_{\mathrm{f}}}{\mathrm{t}} \times 60
$$

Where, $(\mathrm{TP})_{\mathrm{c}}=$ Throughput capacity, $\mathrm{kg} / \mathrm{hr} ; \mathrm{m}_{\mathrm{f}}=$ Mass of gari collected, $\mathrm{kg} ; \mathrm{t}=$ Time taken, $\min$

The functional/drying efficiency is a percentage of the garri output to the cassava mash input.

$\eta_{\mathrm{f}}=\frac{\mathrm{m}_{\mathrm{f}}}{\mathrm{m}_{\mathrm{i}}} \times 100$

Where, $\eta_{\mathrm{f}}=$ Functional/drying efficiency, $\% ; \mathrm{m}_{\mathrm{f}}=$ Mass of garri obtained, $\mathrm{kg} ; \mathrm{m}_{\mathrm{i}}=$ Mass of mash introduced into the fryer, $\mathrm{kg}$.

In the determination of Throughput Capacity and Functional Efficiency, the machine speed was set to 20 rpm and $8 \mathrm{~kg}$ charcoal was used as the source of heat energy for the frying. Cassava mash of $12 \mathrm{~kg}$ with initial moisture content of $42 \%$ wet bulb was poured into the frying chamber preheated to temperature of $45^{\circ} \mathrm{C}$. The introduction of the mash was done at intervals. Firstly, $3 \mathrm{~kg}$ of mash was poured into the frying chamber and fried for first two minutes, followed by $4 \mathrm{~kg}$ and fried for next four minutes before finally adding the remaining $5 \mathrm{~kg}$. This assists in the prevention of burning and formation of cake or lumps. The cassava mash was in constant agitation with the aid of the frying paddles. The process was done for 23 minutes with the temperature of the chamber not exceeding $100^{\circ} \mathrm{C}$ during the process, while the frying paddles operated at the speed of $20 \mathrm{rpm}$.

A Sample of the processed garri is then analyzed to determine the moisture content for each experimental run.

In addition to the performance parameters analysis, some variables that affect the time required for the production of finished product (garri) are considered. They include: machine speed and mash input quantity.

In the determination of preferred paddle speed, $12 \mathrm{~kg}$ cassava mash of $42 \%$ initial moisture content was poured into the fryer and the paddle speed was set at $100 \mathrm{rpm}$ using $8 \mathrm{~kg}$ charcoal as a source of heat energy for frying. The cassava mash was intermittently supplied to the frying chamber. This was repeated for speed of $80 \mathrm{rpm}, 60 \mathrm{rpm}, 40 \mathrm{rpm}$ and $20 \mathrm{rpm}$ respectively with other parameters kept constant and frying time of 23 minutes. Furthermore, in determining the effect of initial frying chamber temperature on quality of the processed garri. The initial experimental procedure was repeated for frying temperatures range of $45^{\circ} \mathrm{C}$ to $60^{\circ} \mathrm{C}$ for a $12 \mathrm{~kg}$ mass of the cassava mash using the shaft speed of $20 \mathrm{rpm}$ and $8 \mathrm{~kg}$ charcoal as a source of heat energy. Finally, considering quantity of mash with time of frying, the quantity of mash introduced into the frying chamber was varied $(5 \mathrm{~kg}$, 
$7.5 \mathrm{~kg}, 10 \mathrm{~kg}, 12.5 \mathrm{~kg}$ and $15 \mathrm{~kg}$ ). Test parameters utilized are: initial moisture content of the cassava mash as $42 \%$; paddle speed of $20 \mathrm{rpm}$ and $8 \mathrm{~kg}$ charcoal.

\section{RESULTS AND DISCUSSION}

From Table 1, the average mass of garri obtained was $7.92 \mathrm{~kg}$ at final moisture content of $12.12 \%$ w.b. after a frying time of 23 minutes. The test parameters used in this experiment are $12 \mathrm{~kg}$ cassava mash with initial moisture content of $42 \%$ w.b. at paddle speed of $20 \mathrm{rpm}$. Lastly, the throughput capacity and functional efficiency are $20.66 \mathrm{~kg} / \mathrm{hr}$ and $66 \%$ respectively. Figure 3 presents the result of the effect of the paddle speed on the cooking and drying rate of cassava mash. Paddle speeds ranging from $20 \mathrm{rpm}$ to $100 \mathrm{rpm}$ were utilized for a frying time of 23 minutes, the finished garri obtained varied in quality with respect to the speeds. The speed was directly proportional to the final moisture content. Between 40rpm and 100rpm, there was relatively high moisture content above the safe value for garri storage. However, at paddle speed of $20 \mathrm{rpm}$ a moisture content value of $12.14 \%$ w.b. was achieved which is in line with the standard recommended by CODEX. Therefore the observed paddle speed of $20 \mathrm{rpm}$ of the machine was selected as preferred paddle speed.

Table 1: Determination of machine performance parameters

\begin{tabular}{|c|c|c|c|c|c|c|c|}
\hline $\begin{array}{l}\text { Experimental } \\
\text { Runs }\end{array}$ & $\begin{array}{l}\text { Initial } \\
\text { Moisture } \\
\text { Content } \\
\text { (\% w.b.) }\end{array}$ & $\begin{array}{l}\text { Final } \\
\text { Moisture } \\
\text { Content } \\
\text { (\% w.b.) }\end{array}$ & $\begin{array}{l}\text { Mass of mash } \\
\text { introduced } \\
\text { into the } \\
\text { fryer, } m_{i}(\mathrm{~kg})\end{array}$ & $\begin{array}{l}\text { Mass of } \\
\text { garri } \\
\text { obtained, } m_{f} \\
(\mathrm{~kg})\end{array}$ & $\begin{array}{l}\text { Frying } \\
\text { time, } \mathbf{t} \\
(\mathrm{min})\end{array}$ & $\begin{array}{l}\text { Throughput } \\
\text { capacity, } \\
(\mathrm{TP})_{\mathrm{c}} \\
(\mathrm{kg} / \mathrm{hr})\end{array}$ & $\begin{array}{l}\text { Functional } \\
\text { efficiency, } \eta_{\mathrm{f}} \\
(\%)\end{array}$ \\
\hline 1 & 42 & 12.3 & 12 & 7.85 & 23 & 20.48 & 65.42 \\
\hline 2 & 42 & 12.5 & 12 & 8.04 & 23 & 20.97 & 67.00 \\
\hline 3 & 42 & 11.85 & 12 & 7.9 & 23 & 20.61 & 65.83 \\
\hline 4 & 42 & 12.02 & 12 & 7.94 & 23 & 20.71 & 66.17 \\
\hline 5 & 42 & 11.93 & 12 & 7.87 & 23 & 20.53 & 65.58 \\
\hline AVERAGE & 42 & 12.12 & 12 & 7.92 & 23 & 20.66 & 66.00 \\
\hline
\end{tabular}

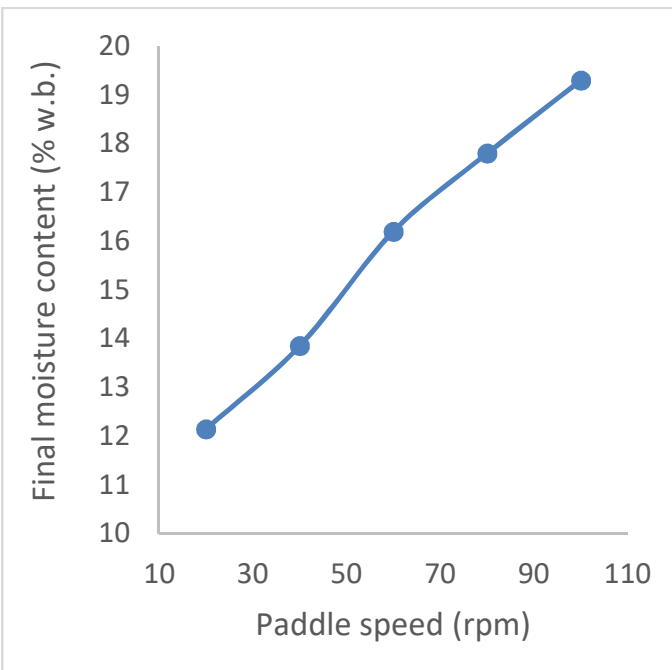

Fig 3: Effect of Paddle Speed on Final moisture content

From Figure 4, the final moisture content obtained for five experimental runs from the cassava mash masses of $5 \mathrm{~kg}, 7.5 \mathrm{~kg}, 10 \mathrm{~kg}, 12.5 \mathrm{~kg}$ and $15 \mathrm{~kg}$ are $10 \%$ w.b., $10.8 \%$ w.b. and $11.6 \%$ w.b., $12.4 \%$ w.b. and $14.2 \%$ w.b. respectively.

It can be deduced that at constant frying time, the higher the quantity of mash introduced into the fryer, the higher the garri final moisture content. Therefore, it can be deduced that frying time is directly proportional to quantity of cassava mash fed into the frying chamber for processing.

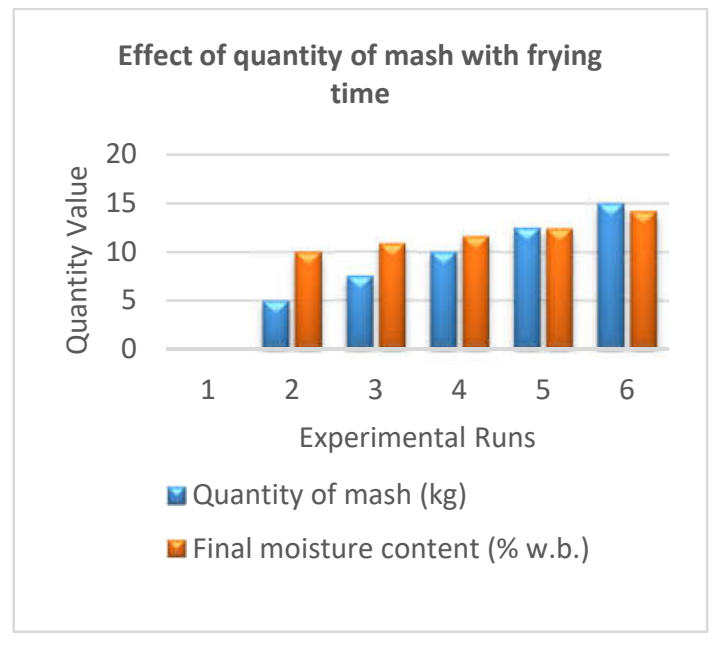

Fig 4: Effect of quantity of mash with frying time

Conclusion: A vertical paddle semi-automated garri frying machine was developed and evaluated in this study. The cooking and drying performance of the developed machine accounted for throughput capacity of $20.66 \mathrm{~kg} / \mathrm{hr}$ and functional efficiency of $66 \%$. In addition, a preferred final moisture content of $12.14 \%$ w.b. was achieved at $20 \mathrm{rpm}$ paddle speed and frying time of 23 minutes. Results obtained showed that the machine can effectively fry garri following the performance indicators outlined. The development of this equipment adopted the village technique whose garri product have been adjudged to have the best quality till date but addressed the short coming 
observed in the technique such as time-consumption, health hazard for the operator. The machine is user friendly, requires no skilled labour and also uses different heat sources for convenience of the user.

\section{REFERENCES}

Akinyemi, JO; Akinlua, (1999). Design, Construction and Testing of Cassava Grater. International Journal of Tropical Agriculture. 17(1-4); 103108.

AOAC (1990). Official Method of Analysis.15th edition. Association of Official Analytical Chemist, Washington D C, USA. 95-224.

Codex Standard 151 (1989). Codex Standard for Gari. Adopted 1989. Revision 1995. Amendment 2013.

Gbasouzor, AI; Maduabum, AIV (2012). Improved Mechanized Gari Frying Technology for Sustainable Economic Development in Nigeria. Proceedings of the International Multi Conference of Engineers and Computer Scientist. 2, IMEC.

Igbeka, JC (1995). Recent developments in cassava frying operation and equipments used for gari productiionn Nigeria, Transformation Alimentaire du Manioc, pp 582-593.

IJFST (1989). International Journal of Food Science and Technology, 24(6) 637-645.

Khurmi, RS; Gupta, JK (2005). A Textbook of Machine Design (S.I. Units) Eurasis Publishing House (PVT) Limited, New Delhi-11005S.

Odigboh, EU; Ahmed, SF (1984) Design of a continuous-process gari frying machine, NIJOTECH, Vol. 8(1), 25-33.

Odigboh, EU (1983). Cassava Production, Processing and Utilization. In: Chan Jnr., H. T. (ed), Handbook of Tropical Foods. Marcel Decker Publisher, Inc.; 270, Madison Avenue, New York; 145-200.
Ohimain, EI; Silas-Olu, DI; Zipamoh, JT (2013). Biowastes Generation by Small Scale Cassava Processing Centres in Wilberforce Island, Bayelsa State, Nigeria. Greener Journal of Environmental Management and Public Safety. Vol. 2 (1), 051059.

Olagoke, OA; Olawale, JO; Mohammed, D (2014). Performance Evaluation of an Automated Gari Fryer. The International Journal of Engineering and Science (IJES), 3 (2), 39-46.

Olukunle OJ; Atere, AO (2009). Developments in Cassava Peeling Mechanisation. Proceedings of the International Conference the Nigerian Institution of Agricultural Engineers/West African Society of Engineers, held at Obafemi Awolowo University, Ile -Ife

Olukunle OJ; Oguntunde PG (2008). Analysis of Peeling Pattern in an Automated Cassava Peeling System. Nigerian Journal of Technological Development, 6 (1\&2) 41-52

Olukunle, OJ; Ademosun, OC (2006). Development of a double action self -fed cassava peeling machine. Journal of food, Agriculture and Environment (JFAE), Accepted for publication

Olusegun, HD; Ajiboye, TK (2009). The Design, Constrution and Testing of a Vertical Squeeze Cassava Pulp Dewatering Machine, Journal of Applied Sciences Research, 5(10): 1285-1297.

Oyerinde, AS; Olalusi, AP (2011). Thermal Properties of Ground and Fermented Cassava Mash (Gari) during Different Stages of Roasting. Journal of Industrial Research and Technology, 3(1) 5-9.

Rufus Ogbuka, C; Odo, FO (2018). Analysis of Garri Frying Machine Manufacturing in Nigeria: Design Innovation Advances in Science, Technology and Engineering Systems Journal Vol. 3(6), 403-411. 